\title{
Lake-level changes in the past 50 ka reconstructed from the lacustrine delta deposits in Kathmandu Valley, Nepal
}

\author{
1 Department of Geoscience, Shimane University, Matsue 690-8504, JAPAN \\ 2 Department of Geology, Trichandra Collage, Tribhuvan University, Kathmandu, NEPAL \\ 3 Applied Satoyama Study Laboratory, 1773-2 Yoshikawa-cho, Mino 501-3721, JAPAN \\ 4 ONP Laboratory, 21-30 Tai-cho, Neyagawa 572-0021, JAPAN \\ * For correspondence, email: sake@riko.shimane-u.ac.jp
}

Tetsuya Sakai ${ }^{*}$, Ananta P Gajurel ${ }^{2}$, Hideo Tabata ${ }^{3}$, Nobuo Ooi ${ }^{4}$ and Bishal N Upreti

This study aims to elucidate lake-level changes in the past 50 $\mathrm{ka}$ from the deltaic succession exposed in the northern part of Kathmandu Valley, Nepal. The thick pile of the lacustrine delta succession (Gokarna, Thimi, Tokha and Patan Formations) exposed at 1,300-1,420 $\mathrm{m}$ above sea level (masl) allows reconstruction of the lake-level curve, based on estimation of paleolake levels within the deltaic succession and using 14C dating.

The paleolake levels were estimated based on facies analysis, which showed that the bulk of the sediments were deposited in the subaerial part of the lacustrine delta (fluvial, marsh and flood plain deposits). The levels of the sampling points for dating thus correspond to the lake level at the time of deposition. In addition, the following stratigraphic information was incorporated for delineating the curve: (1) sediments deposited during a rapid lakelevel-fall event due to lake outburst were discovered in the Gokarna Formation. The event bed was dated as $39 \mathrm{ka}$, and the associated erosion surface was discovered in the succession at about 1,340 masl; the lake level reached 1,340 masl and then fell rapidly down to 1,300 masl, at which point the fluvial deposits after the event were deposited. (2) Because the top of the Gokarna Formation was truncated prior to the deposition of the Tokha Formation, the precise height of the top of the Gokarna Formation is unknown in the north Kathmandu Valley. In the eastern part of the basin, the top of the Gokarna Formation seems to have escaped the subsequent erosion. The top of the formation at this site was 14C-dated at 35 ka. (3) The age of the lake draining is still uncertain. The youngest age formerly obtained from the lake sediments was $11 \mathrm{ka}$ : ca. $10 \mathrm{ka}$ is the most plausible age for the draining by another lake outburst. Just before the lake vanished, the lake-level reached 1,320 masl.

Two lake-level rise events around $34 \mathrm{ka}$ and $19 \mathrm{ka}$ are depicted in the curve; both were followed by rapid lake-level falls. These falls may also have been due to lake outbursts such as the 39 ka event, but do not represent climatic signals in Kathmandu Valley. However, the lake-level-rise events can be recognized as climate signals, because they occurred in an underfilled condition. The lake-level rises around $34 \mathrm{ka}$ and $19 \mathrm{ka}$ seem to reflect the humid climate. In particular, the lake-level rise around $34 \mathrm{ka}$ is synchronized with the enhanced Indian monsoon recorded in the intermontane basins of the Himalayas (e.g. Kumaun Himalaya) and in the ice cores and lake-level records in Tibet. The $19 \mathrm{ka}-$ rise event may have caused by reduction in evaporation and slight increase in precipitation. The humid climate condition in this period has been also detected by pollen analysis in Kumaun Himalaya, and by the higher water level than present identified in the lakes of western Tibet. This humid condition was probably brought by westerlies, the effect of which may have spread farther south than previous estimates based on the distribution of the glaciated area during the last glacial maximum. 